\title{
Public Debt Spiral in Nigeria: Can a Structural Gap Result From Pervasive Corruption?
}

\author{
Fisayo Fagbemi \\ Independent Researcher \\ Nigeria \\ E-mail: fisay4real@yahoo.com \\ Olufemi Solomon Olatunde \\ Independent Researcher \\ Nigeria \\ E-mail: olufemi.olatunde@gmail.com
}

\begin{abstract}
It is increasingly recognized that good understanding on the corruption-related causes and remedies of the modern fiscal crisis would bolster informed decisions and key governance standards. Many of the governance weaknesses have been exacerbated by ingrained fiscal indiscipline and lack of effective bureaucratic provisions. These concerns necessitate ongoing research efforts aimed at galvanizing the best compilation of perspectives on the role of public institutions in debt accumulation process. Hence, this study examines the long run and short run effect of corruption on public debt in Nigeria over the period of 1996 to 2017 using ARDL bound test to cointegration analysis. Empirical evidence reveals that both corruption index and control of corruption have an insignificant adverse effect on public debt in the long run, but with a significant influence in the short run. Considering the long-term implication, current anti-corruption efforts might be ineffective in enhancing strategic monitoring and sustainable fiscal standards. Nonetheless, it is emphasized that effective corruption control measures could mitigate spiralling incidence of government debt. Further findings indicate that there exists bi-directional causality between corruption index and public debt, whereas none is found between control of corruption and public debt. The study suggests that strong corruption-based control mechanisms are fundamentals to decreasing fiscal deficits and debt reduction. Overall, a significant insight distills from the study is that the goal of attaining global financial stability and fiscal sustainability through sound regulatory framework has embodied the provisions that enhance corruption-reducing measures and institutional standards to curb persistent debt accumulation.
\end{abstract}

Keywords: Public debt, Corruption, Fiscal crisis, ARDL, Nigeria.

\section{Introduction}

The orthodox stance on the concept of structural gap is that when fiscal revenues of the state are insufficient to finance everincreasing public expenditures. With increasingly unsustainable government spending levels in the social and economic development process, the state faced a huge financing deficit. Hence, evolving empirical expositions reveal that structural gaps could lead to spiraling incidence of public borrowing and debt (Bailey, 2004). In this context, structural gap and 'fiscal crisis' are synonymous. In most developing economies, the public debt trajectory has approached unsustainable levels which threaten the fiscal health of countries. Many African countries, in particular, are struggling with a combination of rising public debt, budget deficits and poor growth. Over the years, much of this debt upsurge is driven by an absence of fiscal discipline and sound corruption control measures. The injudicious choices for debt accumulation posed a problem to citizens of such indebted jurisdiction, since future servicing of public debt with no long-term development impact would exacerbate intergenerational inequity (Liu, 2017). Some economists (researchers), in general, have espoused to the adverse effect of government debt on economic growth and development in any economy (Kumar \& Woo, 20I0; Reinhart, Reinhart \& Rogoff, 20I2). Thus, debt deliberately amplified through corrupt actions may be inimical to fiscal performance and the economy as a whole.

Recognizing that a robust fiscal state is a springboard for socio-economic development, in sub-Saharan Africa (SSA), recent years have witnessed a great deal of policy actions initiated to bolster the fiscal position of the central government across countries. Nonetheless, political leaders and economic actors often reinforce the formation of large structural gaps in SSA

${ }^{\text {I }}$ Fiscal crisis occurs when there is a substantial increase in much-needed government expenditures over state revenues, which give rise to insufficient finance. 
countries. In Africa, the culture of self-serving ethos and dishonest political control are ubiquitous. Due to high levels of corruption and inefficient resource utilization, public debt has turned out to be a new succession of slavery for most countries in the region. The biggest challenge confronting SSA is how the borrowed funds can be utilized. Nigeria, indeed, best fits this scenario, as pervasive corruption impedes strict adherence to fiscal rules and prudence in the country. In Nigeria, the advent of civil rule in 1999 has led to the introduction of anti-corruption initiatives by the successive governments. Despite these, coupled with institutional control measures, corruption is festering. According to transparency international, Nigeria is one of the most corrupt countries in the world. The Corruption Perceptions Index (2018) shows that out of 175 countries ranked, Nigeria is the I44 least corrupt nation — close to the bottom of the ranking.

The alarming proportion of Nigeria's public debt which could have an adverse effect on the development path of the country has escalated debate among policymakers, in spite of the argument of government's financial managers. Given the Debt Management Office (DMO) report, the country's total debt stood at N22.43 trillion in 2018, a rise of 85.06 per cent when compared with what it was in June 2015 (Leadership Nigeria Newspaper, 2018). The percentage of public debt to GDP has been on the rising side vis-à-vis low corruption index (Figure I). It is worrisome that Nigeria is approaching the pre-2005 Paris Club levels. The causes of and responsive approach to the fiscal crisis are being viewed by researchers. Following call for restraining the escalation of public debt, the goal of attaining global financial stability and fiscal sustainability through sound regulatory reform has embodied the provisions that enhance the institutional framework for addressing frail fiscal levels in developed and emerging economies. However, the literature on the role of political and bureaucratic factors in public debt accumulation process is sparse, perhaps still budding in developing countries. Thus, the question as to whether the high level of corruption magnifies the growing incidence of indebtedness of Nigeria's government should be accorded considerable attention.

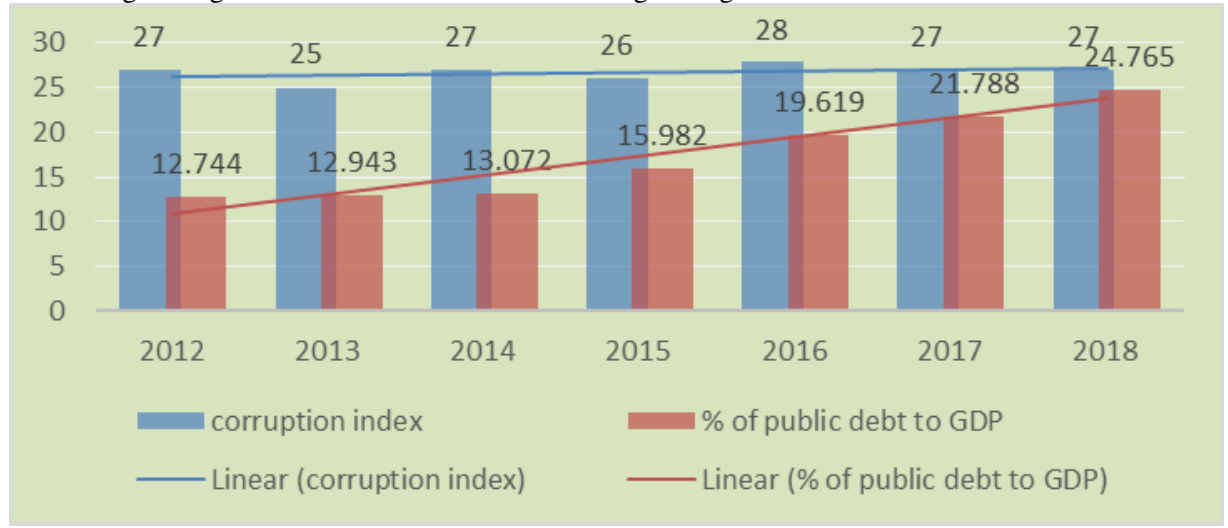

Figure I: corruption index and \% of public debt to GDP (2012-2018)

Source: Authors' estimates based on data from transparency international and IMF

World Economic Outlook database (2018)

Furthermore, most findings on the relationship between corruption and public debt are cross-country studies (Alfredo \& Luca, 2015; Cooray et al., 2017; Benfratello et al., 2018), whereas, regarding Nigeria, major studies center on the nexus between corruption and economic performance (Obadan, 2002; Osunyikanmi, 2007; Adewale, 201I). Hence, like the way Grechyna (2012) opines that there is need for convincing empirical evidence of the effect of corruption on public debt for high-income countries, a study that will examine the influence of corruption on the rising debt profile in Nigeria is central. The main reason advanced for this study is the paucity of systematic analysis significant for enhancing holistic expositions that would drive robust regulatory response to escalating fiscal crisis. Specifically, the study's key objective is to explore the long-run and short run relationship between corruption and public debt in Nigeria.

The rest of the paper is organized as follows. In section 2, literature review is presented. Data description and detailed econometric techniques adopted are provided in section 3. Section 4 is the presentation of results and discussion, while the last section (section 5) gives the concluding remarks.

\section{Literature review}

\section{I Theoretical and conceptual discussion}

Over the years, many scholars have dealt with various institutional and economic factors that could navigate fiscal operations in any economy. The close nexus between feeble bureaucratic system and shadow economy ${ }^{2}$ has a substantial influence on the performance of fiscal institutions. For instance, (Friedman, Johnson, Kaufmann, \& Zoido-Lobaton, 2000; Schneider, Buehn, \& Montenegro, 2010) contend that a larger shadow economy results from high corruption. The two concepts are closely related

${ }^{2}$ Although there seems to be no consensus exists as to the precise definition of the shadow economy, the concept can be viewed as an unobservable (unrecorded) economic phenomenon (Buehn \& Schneider, 2009). 
and analogous ${ }^{3}$, as both involve illegal activities such that the market-based production of goods and services remains elusive in official GDP estimates (Tanzi, 1998; Smith, 1994). Accordingly, by compromising the capacity of the government to collect taxes and fees, corruption gives rise to revenue shortfalls (Arusha \& Friedrich, 2013). Given that a corrupt bureaucracy alters the design, structure and functionality of fiscal arrangement, the effectiveness of public investment and infrastructure is undermined by increasing opacity in the public sector (Dzhumashev, 20I4a). In any case, the quality of institutions shapes the effect of government spending, and hence determines the growth rate of public debt.

Another theoretical linkage in the literature is anchored on the elite theory. The theory emphasizes that, at the governance level, the perpetrators of corruption are mostly the elite class. Proponents of the theory assert that public policy is shaped by the preferences and values of the governing elite (Gaetano Mosca (I858-194I); Jose Ortega (I855-1983); Vilfredo Pareto (1923-1948)). They elucidate that every society is controlled by a group of persons enjoying superior intellectual or social and economic status necessary for its accession to full political and economic power. This group manipulate the structures and institutions of politics to suite their private ends (selfish purposes). Moreover, the ideological and philosophical direction of the society are determined by a minority. The development of governing class in most developing economies is strongly linked with their colonial background ${ }^{4}$. Specifically, in Nigeria, the elite group has features similar to its colonial progenitor — an instrument of exploitation and a means for primitive resource accumulation. Public policy is characterized by ill-informed decisions and sharp corrupt practices of the ruling class, which undermine fiscal performance, and in turn, the retardation of economic growth and development (Obialor, 2017).

The literature on rent-seeking theory which emphasizes the pursuit of private gains by public administrators at the expense of the common good also offers an explanation on corruption-fiscal nexus. Corruption which is often viewed as the "misuse of public office for private gain" (Mauro, 1995) could facilitate rent-seeking behavior in the public sector. A corrupt environment is characterized by an extreme case of violated legal rules and the pervasiveness of questionable illegal activities. Corruption is an unconstitutional pursuit of selfish goals by public officials (Liu, 2017). Previous studies have stressed that government officials are likely to espouse to large capital investments, as they engender maximum rent seeking. Owing to nontransparent bureaucracy, the effectiveness of various financial assistance programs is hampered, because funds are often channeled away from the intended purposes. In such economies, prior evidence posits that it is rampant to bribe officials who can exert political leverage in public contracts and regulation-related industries (Kaufmann 2010; Liu and Mikesell, 20I4). Thus, public expenditure is deemed to be wasteful due to injudicious choices (Shleifer and Vishny 1993; Tanzi and Davoodi 1997). Overall, there is evidence that corruption exacerbates inequalities and poverty in a country through the distortion in the composition of public spending (Delavallade, 2006; Mauro, 1998). Historically, as most government projects are financed primarily through borrowed funds, some authors opine that presence of corruption will induce increased public debt, ceteris paribus (Butler, Fauver and Mortal, 2009; Liu, 2017).

\subsection{Empirical evidence}

With the expansion of public debt in most economies, establishing a convincing ground that could consolidate the role of institutional control measures in the economy is central. In light of this, empirical studies bolster up the ulterior reasons for supporting that a link between corruption and the level of public debt is tenable, as many researchers argue that corruption may affect government debt through various channels. For example, Tanzi and Davoodi (1997) support the notion that an increase in public spending could be reinforced by corruption. Similarly, Dzhumashev (20I4b) corroborating this view with assertion that the perpetuation of large public expenditures may result from the interplay of high levels of corruption and public spending. Furthermore, given that the composition of public spending can be altered by corrupt elements, Mauro (1998); Wei (200I) indicate that more resources may be allocated to sectors which involve less transparency (like defense) against the vital sectors (such as health and education), because military expenditure is most often not subject to the usual auditing and frequent public legal scrutiny (Gupta, De Mello \& Sharan, 200I). Thus, public debt would increase as large-scale investment projects and public expenditures (such as defense) are financed by both internal and external borrowing, (Kaufmann, 2010).

Moreover, using a panel of 166 countries between 1995 and 2013, Luigi, Alfredo \& Luca (2015) examine the relationship between corruption and public debt. The authors show that high corruption in the public sector is found to increase government debt. Based on a large panel of countries between 1995 and 2015, Benfratello et al. (2018) assess the impact of corruption on public debt. Results indicate that corruption leads to increased public debt, but the effect seems to be heterogeneous across income-related sample splits; such that in advanced economies, it is stronger, while in less-developed countries, it appears to be weaker and less statistically robust. Pani (1996) focuses on the effects of corruption on the macroeconomic variables of the public budget. The study analysis centers on the situation whereby the management of public expenditure is induced by public bribes, in the long term, it is stressed that these corrupt acts could accentuate an accumulation

\footnotetext{
${ }^{3}$ For example, Arusha, Ratbek, \& Friedrich (2017) posit that a larger shadow economy and high corruption in an economy trigger spiralling public debt.

${ }^{4}$ In Nigeria, with propensity for unbridled materialism, the culture of self-serving ethos was imbibed by the country's elites who took over power from the erstwhile colonial administrations. Their actions were mostly influenced by the exploitative tendencies (activities) of the colonial masters (Ojukwu and Shopeju, 2010:5).
} 
of debt that might result to financial crisis in the country, although the outcome depends on some prevailing factors — the incentives with which it is confronted and preferences of the government. Cooray et al. (2017) using Ordinary Least Squares (OLS), fixed effects, system generalized method of moments (GMM) and instrumental variable estimation, examine the relationship between corruption, the shadow economy and public debt. With the use of two measures of corruption (the Transparency International Corruption Perceptions Index and the Kaufmann et al., 2010 — corruption index) for I26 countries over the period of 1996-2012, estimates reveal that increased corruption and a larger shadow economy result to a rise in public debt. Employing the system generalized method of moment (GMM) estimator, Njangang (2018) explores the impact of corruption on public debt with a panel of 29 Sub Saharan African countries (SSA) between 2000 and 2015. Although recognizing that a large literature concludes on the damaging effect of corruption on any economy, findings reveal that corruption positively influences public debt in the sample countries.

On the other hand, some authors argue that corruption adversely affect the economic performance as a whole (Hall \& Jones, I999; Kraay, Zoido-Lobaton, \& Kaufmann, 1999). In particular, corruption retards the level of investment (Mauro 1995), and it also undermines the quality of procurement services (Rose-Ackerman 1997). Other studies on the effect of corruption on most economies also corroborate these conclusions (Johnson, Kaufmann \& Shleifer, 1997; Depken \& LaFountain, 2006). Analogously, with a focus on Nigeria, corrupt practices are found to be inimical to the economic system (Obadan, 2002; Osunyikanmi, 2007; Adewale, 201I). They further posit that corruption impairs hard work, accountability and efficiency. In general, there exists a significant adverse relationship between corruption and output growth in Nigeria. However, the preceding review underscores that evidence on the influence of corruption on fiscal level is sparse. There is limited understand on how it accentuates fiscal impacts. By and large, a sufficient gap is left for a study assessing how corruption affects the spiralling incidence of public debt in Nigeria.

\section{Data and Methodology}

\section{I Data description}

Given the systematic significance of the main objective, the study employs annual time series data between I996 and 2017. Based on the availability of data, the choice of scope is vital for establishing a robust ground on the role of public institutions in fiscal development process. In the study, two indicators of corruption are used - the Transparency International Corruption Perceptions Index and the Kaufmann et al., 2010 (corruption index). The percentage of public debt to GDP is included as the dependent variable in the model. While taking into account the relevance of certain variables in governance-fiscal literature, GDP per capita, inflation rate, consumer prices (annual \%) and gross national expenditure (\% of GDP) are employed as control variables. Accordingly, detailed description and the corresponding data source are given in Table I.

Table I: Variable description

\begin{tabular}{|c|c|c|}
\hline Variable & Description & Source \\
\hline \multicolumn{3}{|l|}{ Fiscal indicator } \\
\hline$\%$ of debt to GDP & $\begin{array}{l}\text { It is the ratio of a country's public debt to its } \\
\text { gross domestic product (GDP). }\end{array}$ & $\begin{array}{l}\text { IMF historical public debt database } \\
(2018)\end{array}$ \\
\hline \multicolumn{3}{|l|}{ Corruption indicator } \\
\hline $\begin{array}{ll}\text { Transparency } & \text { International } \\
\text { Corruption Index } & \end{array}$ & $\begin{array}{l}\text { It shows the perceived level of public sector } \\
\text { corruption on a scale of } 0 \text { (highly corrupt) to } \\
\text { I00 (very clean). }\end{array}$ & Transparency international (20I8) \\
\hline $\begin{array}{l}\text { Kaufmann et al., } 2010 \text { (control of } \\
\text { corruption) }\end{array}$ & $\begin{array}{l}\text { It captures perceptions of the extent to which } \\
\text { public power is exercised for private gain, } \\
\text { including both petty and grand forms of } \\
\text { corruption, as well as "capture" of the state } \\
\text { by elites and private interests. Estimate gives } \\
\text { the country's score on the aggregate } \\
\text { indicator, in units of a standard normal } \\
\text { distribution. The close the index to negative, } \\
\text { the worse the institutional quality ( }-2.5 \text { to } \\
2.5) \text {. }\end{array}$ & $\begin{array}{l}\text { World governance indicators ( } 2018 \\
\text { edition) }\end{array}$ \\
\hline \multicolumn{3}{|l|}{ Macroeconomic indicator } \\
\hline GDP per capita & $\begin{array}{l}\text { GDP per capital (constant } 20 \text { I0 US\$), It is } \\
\text { expected to be indirectly linked to public } \\
\text { debt. }\end{array}$ & $\begin{array}{l}\text { World development indicators ( } 2018 \\
\text { edition) }\end{array}$ \\
\hline Inflation rate & $\begin{array}{l}\text { Inflation rate is measured by consumer price } \\
\text { index (annual \%). It is expected to positively }\end{array}$ & $\begin{array}{l}\text { World development indicators ( } 2018 \\
\text { edition) }\end{array}$ \\
\hline
\end{tabular}


affect public debt.

\begin{tabular}{ll}
\hline Gross national expenditure (\% of & It represents the sum of household final World development indicators (2018 \\
GDP) & consumption spending, general public final edition) \\
& consumption expenditure and gross capital \\
& formation. Theoretically, it is positively \\
& correlated with public debt.
\end{tabular}

\subsection{Methodological framework}

Following the preceding theoretical linkage between corruption and fiscal levels (Butler, Fauver and Mortal, 2009; Liu and Mikesell, 20I4), a linear regression model is formulated in a functional form as;

$D E B T_{t}=f\left(\right.$ CORR $_{t_{\mathrm{s}}} G D P_{\mathrm{t}_{\mathrm{s}}} I N F_{\mathrm{t}_{\mathrm{s}}}$ EXP $\left._{\mathrm{t}}\right)$

Where DEBT is defined as \% of debt to GDP. CORR represents corruption index. GDP is the GDP per capita. $I N F$ connotes inflation rate while EXP is the Gross national expenditure (\% of GDP). $t$ indicates the time period.

\subsection{Cointegration technique}

As many econometric techniques exist for finding the long run relationship among variables, Autoregressive Distributed Lag (ARDL) model has been viewed to be more efficient and reliable given its numerous advantages over others (Engle-Granger, 1987; Johansen and Juselius, I990; Johansen, 199I). Unlike other cointegration methods, where the order of integration matters and the requirement for large sample size, ARDL approach developed by Peseran and shin (1997); Pesaran, et al. (200I) is applicable irrespective of the order of integration (i.e. whether it I (O) or I (I), it does not matter). It is also effective for small sample . With ARDL, long run and short run relationship can be allowed for within the same model. In view of these, and considering the small sample size of the study, ARDL bound test to cointegration is applied. Hence the model is stated as follows:

$$
\begin{aligned}
\Delta \ln D E B T_{\mathrm{t}}=\alpha & +\sum_{\mathrm{i}=1}^{m 1} \beta_{1} \Delta \ln D E B T_{\mathrm{t}-\mathrm{i}}+\sum_{\mathrm{i}=0}^{m 2} \beta_{2} \Delta \operatorname{CORR}_{\mathrm{t}-\mathrm{i}}+\sum_{\mathrm{i}=0}^{\mathrm{ma}} \beta_{\mathrm{a}} \Delta \ln G D P_{\mathrm{t}-\mathrm{i}}+\sum_{\mathrm{i}=0}^{m 4} \beta_{4} \Delta I N F_{\mathrm{t}-\mathrm{i}} \sum_{\mathrm{i}=0}^{\mathrm{m} 5} \beta_{5} \Delta \ln E X P_{\mathrm{t}-\mathrm{i}} \\
& +\vartheta_{1} \ln D E B T_{\mathrm{t}-1}+\vartheta_{2} \operatorname{CORR}_{\mathrm{t}-1}+\vartheta_{\mathrm{a}} \ln G D P_{\mathrm{t}-1}+\vartheta_{4} I N F_{\mathrm{t}-1}+\vartheta_{5} \ln E X P_{\mathrm{t}-1}+v_{\mathrm{t}}
\end{aligned}
$$

The white noise error is represented by $v$. In is the log of variables while the difference operator is defined as $\Delta$.

In Eq. (2), $m 1, m 2, \ldots \ldots, m 5$ indicate the optimal lag length determined by information criterion. Using bound test approach (Pesaran et al., 200I), the cointegration relationship between DEBT and other variables (explanatory) can be found with the placing of restriction on the whole estimated parameters of lagged level variables to be equal to zero. In this case, the null hypothesis is stated as; $H_{0}: \vartheta_{1}=\vartheta_{2}=\vartheta_{a}=\vartheta_{4}=\vartheta_{5}=0$, against alternative hypothesis; $H_{1}$ : $\vartheta_{1} \neq \vartheta_{2} \neq \vartheta_{a} \neq \vartheta_{4} \neq \vartheta_{5} \neq 0$. In this model, the null hypothesis states that there is no long run relationship among the variables. On the other hand, the alternative hypothesis implies the presence of long run relationship among the variables. Decision rule: if the computed F-test exceeds the upper bound critical value, $H_{0}$ is rejected. However, if the calculated Fstatistics is less that the lower critical value, $H_{0}$ cannot be rejected, while the decision remains inconclusive, if the calculated Fstatistics lie between the lower and upper bounds. After confirming the existence of cointegration among the variables, an error correction model is specified from Eq. (2) as;

$$
\begin{aligned}
& \Delta \ln D E B T_{\mathrm{t}}=\partial_{0}+\sum_{\mathrm{i}=1}^{m \mathrm{I}} \partial_{1} \Delta \ln D E B T_{\mathrm{t}-\mathrm{i}}+\sum_{\mathrm{i}=0}^{\mathrm{m} 2} \partial_{2} \Delta \operatorname{CORR}_{\mathrm{t}-\mathrm{i}}+\sum_{\mathrm{i}=0}^{\mathrm{m} 2} \partial_{\mathrm{a}} \Delta \ln G D P_{\mathrm{t}-\mathrm{i}} \\
& +\sum_{i=0}^{m / 4} \partial_{4} \Delta I N F_{t-i} \sum_{i=0}^{3 m 5} \partial_{5} \Delta l n E X P_{t-i}+\eta_{i} E C M_{t-1}+v_{t}
\end{aligned}
$$

$\eta$ is the speed of adjustment, which is expected to be negative and significant. $E C M$ indicates the residuals that obtained from the estimation of Eq. (2). Following a shock in the short-run, the negative sign of $E C M$ parameters implies that $D E B T$ adjusts back to its equilibrium value.

4. Empirical Results and Discussion

Taking into account the ineffectiveness and the spurious outcome that may occur when the order of integration in any of the series is I (2), Augmented Dickey Fuller (ADF) and Phillip Peron (PP) unit root tests are performed. Although, in ARDL model, no pre-test is required to ascertain the order of integration, if the level of stationarity is above I (I), the estimates could

${ }^{5}$ The use of ARDL approach circumvents the problem of biasness that often associated with small sample size (see Haug, 2002; Narayan, 2005). 
be inefficient and unreliable. Essentially, results of the tests in Table 2 confirm that no variable is not found to be stationary at first difference. ADF and PP indicate a mixture of I (O) and I (I) in the series. With no I (2) variable in the model, the use of ARDL offers an adequate basis for the study. Also, in Table 3, bounds F-tests are applied to determine the cointegration relationship among the variables. Following Pesaran et al. (200I), the null hypothesis of no cointegration is rejected at I\% significant level in model (i) \& (ii), as the computed F-statistics in both models ${ }^{6}$ are greater than the upper bound critical value. The stability of the parameters in the model is established by Cumulative Sum of Recursive Residuals (CUSUM) and Cumulative Sum of Squares of Recursive Residuals (CUSUMSQ) - in Figure I, the two tests fall within the critical boundaries. The diagnostic tests conducted further verify the validity and robustness of the estimated results.

Table 2. Augmented Dickey Fuller (ADF) and Phillips-Perron (PP) unit root test results

\begin{tabular}{|c|c|c|c|c|}
\hline Variable & \multicolumn{2}{|c|}{ Augmented Dickey Fuller } & \multicolumn{2}{|c|}{ Phillips-Perron } \\
\hline & Level & First difference & Level & First difference \\
\hline Public debt & $-3.69(4)^{2 x+x}$ & $-3.95(0)^{-12 x}$ & -I.I I & $-3.95^{\ldots+x}$ \\
\hline Corruption index & $-2.15(0)$ & $-5.20(\mathrm{I})^{-2}$ & -2.17 & $-10.43^{2}$ \\
\hline Control of corruption & $-\mathrm{I} .9 \mathrm{I}(0)$ & 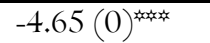 & -2.09 & -4.64 \\
\hline$G D P$ & $-0.80(0)$ & $-3.47(0)^{2}$ & -0.82 & $-3.47^{* \ldots+x}$ \\
\hline Inflation & $-5.93(0)^{x+2 x+x}$ & $-7.07(0)^{-12 x}$ & 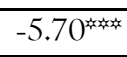 & $-11.35^{\text {shes }}$ \\
\hline National expenditure & $-3.77(0)^{-2 . x}$ & $-5.14(4)^{x}$ & $-3.77^{\text {an }}$ & $-\mathrm{II} .47$ \\
\hline
\end{tabular}

,$\quad \&$ indicates the level of significance at $1 \%, 5 \% \& 10 \%$ respectively. Figures in (.) represents

lag length selected by AIC criterion. The PP length was selected by Newey-West Band Width.

Table 3. Bounds F-tests for cointegration relationship

\begin{tabular}{|c|c|c|c|c|}
\hline Model & $\begin{array}{l}\text { F- } \\
\text { statistics }\end{array}$ & $\begin{array}{l}\text { Level } \\
\text { Significance }\end{array}$ & Critical value & \\
\hline & & & Lower bound & $\overline{\text { Upper bound }}$ \\
\hline Corruption index & $7.28^{x}$ & \multirow{4}{*}{$\begin{array}{l}1 \% \\
5 \% \\
10 \%\end{array}$} & \multirow{4}{*}{$\begin{array}{l}3.74 \\
2.86 \\
2.45\end{array}$} & \multirow{4}{*}{$\begin{array}{l}5.06 \\
4.01 \\
3.52\end{array}$} \\
\hline Model (i) & & & & \\
\hline$(\mathrm{I}, 2, \mathrm{I}, 2, \mathrm{I})$ & & & & \\
\hline $\begin{array}{l}\text { Control of } \\
\text { corruption Model } \\
\text { (ii) } \\
(2,2,2,2,2)\end{array}$ & $18.80^{-x}$ & & & \\
\hline
\end{tabular}

represents statistical significance at I\% level.

In assessing the long run and short run effect of corruption on public debt, Table 4 is presented, and the regression results regarding main measures (corruption indicators) mostly correspond to the apriori expectations. Starting with long run estimates, corruption index (model (i)) has an adverse effect on public debt, suggesting that the higher the index, the lesser the level of public debt. Also, in model (ii), control of corruption is negatively related with the public debt. This implies that an effective corruption control measure could mitigate a high incidence of government debt. Further findings indicate that in both models, the estimated parameters of the two indicators are not significant. A plausible justification for this is that the current ant-corruption efforts might not be well suited to the improvement of public debt management strategy. In another way, it can be stressed that it has a shallow effect on the fiscal management process. In terms of entrenched corrupt bureaucracy and structural gap relations, it is difficult for states with greater fiscal crisis to curb wasteful expenditures and levels of debt. However, given these results, it is evident that, in practice, debt accumulation is restricted with lower levels of public co rruption. This empirical assertion is consistent with previous studies on corruption-public debt nexus (Cooray et al., 2017; Liu, 2017). On the hand, with respect to short run relationship, the estimated parameters of two indicators are significant, while the negative signs are retained. This suggest that, in the short run, the level of corruption substantially navigates the direction of government debt.

Table 4. ARDL long run and short run estimates

\begin{tabular}{llllll}
\hline Variable & Model (i) & & Variable & \multicolumn{2}{c}{ Model (ii) } \\
\hline & Long run & Short run & & Long run & Short run \\
\hline Constant & $0.20^{*}$ & $0.25^{*}$ & Constant & I.03 & $-1.44^{* \ldots+*}$ \\
\hline
\end{tabular}

${ }^{6}$ In this study, model (i) indicates the inclusion of corruption index computed by the Transparency international, whereas model (ii) represents the use of control of corruption developed by Kaufmann et al. (2010) as an institutional indicator in the model. 


\begin{tabular}{|c|c|c|c|c|c|}
\hline & {$[1.99]$} & {$[-2.89]$} & & [2.79] & {$[-12.99]$} \\
\hline Corruption index & $\begin{array}{l}-0.79 \\
{[-1.03]}\end{array}$ & $\begin{array}{l}-0.03^{2} \\
{[-4.29]}\end{array}$ & $\begin{array}{l}\text { Control } \\
\text { cortuption } \\
\end{array}$ & $\begin{array}{l}-1.7 \mathrm{I} \\
{[-0.53]}\end{array}$ & $\begin{array}{l}-0.84^{\text {竞 }} \\
{[-2.78]}\end{array}$ \\
\hline$G D P$ & $\begin{array}{l}-1.27^{\text {taxt }} \\
{[-2.95]}\end{array}$ & $\begin{array}{l}\mathrm{I} .0 \mathrm{I}^{*} \\
{[2.15]}\end{array}$ & $G D P$ & $\begin{array}{l}-0.89 \\
{[-0.32]}\end{array}$ & $\begin{array}{l}-0.85^{\text {and }} \\
{[-2.83]}\end{array}$ \\
\hline Inflation & $\begin{array}{l}0.12 \\
{[0.57} \\
\end{array}$ & $\begin{array}{l}0.02^{\text {axy }} \\
{[3.26]}\end{array}$ & Inflation & $\begin{array}{l}0.47^{\text {好 }} \\
{[1.69]}\end{array}$ & $\begin{array}{l}0.0 I^{\text {稵 }} \\
{[2.04]}\end{array}$ \\
\hline National expenditure & $\begin{array}{l}0.68^{\text {* }} \\
{[1.96]}\end{array}$ & $\begin{array}{l}1.49^{1 / x} \\
{[4.85]}\end{array}$ & $\begin{array}{l}\text { National } \\
\text { expenditure }\end{array}$ & $\begin{array}{l}4.86^{\text {*⿻ }} \\
{[1.77]}\end{array}$ & $\begin{array}{l}1.98^{\text {max }} \\
{[9.89]}\end{array}$ \\
\hline $\operatorname{ECM}(-I)$ & & $\begin{array}{l}-0.1 I^{1} \\
{[-8.42]}\end{array}$ & $\operatorname{ECM}(-I)$ & & $\begin{array}{l}-0.12^{1} \\
{[-13.01]}\end{array}$ \\
\hline D.W & I.94 & & D.W & 2.02 & \\
\hline Ramsey reset test & 0.58 & & Ramsey reset test & $0.5 \mathrm{I}$ & \\
\hline Normality test & 0.53 & & Normality test & 0.58 & \\
\hline Serial correlation & $0.9 \mathrm{I}$ & & Serial correlation & 0.32 & \\
\hline
\end{tabular}

indicate statistical significance at $10 \%, 5 \%$ and $1 \%$ respectively, whilst

figures in $(-)$ are $t$-values.

On the control variables, signs of the estimated parameters also marry up with the theoretical expectation. The results reveal that, in the long run, the effect of GDP per capita remains substantial and statistically significant, indicating that in the period of economic boom, government tends to borrow less compared with the financial crisis period. Similarly, the assertion is also retained in the short run. In contrast, inflation and national expenditure have a direct significant association with public debt in the long run as well as in the short run. Although inflation is insignificant in model (i), high inflation rate and excessive public spending are the fundamental causes of spiralling levels of public debt in Nigeria. In buttressing this empirical ground, large - scale government expenditures on unsustainable projects could exacerbate fiscal imprudence and the rising incidence of indebtedness in the economy (Gupta, De Mello \& Sharan, 200I; Kaufmann, 2010). Moreover, the speed of adjustment of government debt to shocks in exogenous variables is shown by the estimated coefficients of the Error Correction Term (ECM(I)). The negative statistical significance of the estimated parameters of Error Correction Term in the two models indicates a stable process of adjustment to the long run equilibrium. Essentially, the validity of the Error Correction Term $(E C M(-I))$ is established by the estimated values respectively.

Model (i) - Corruption index
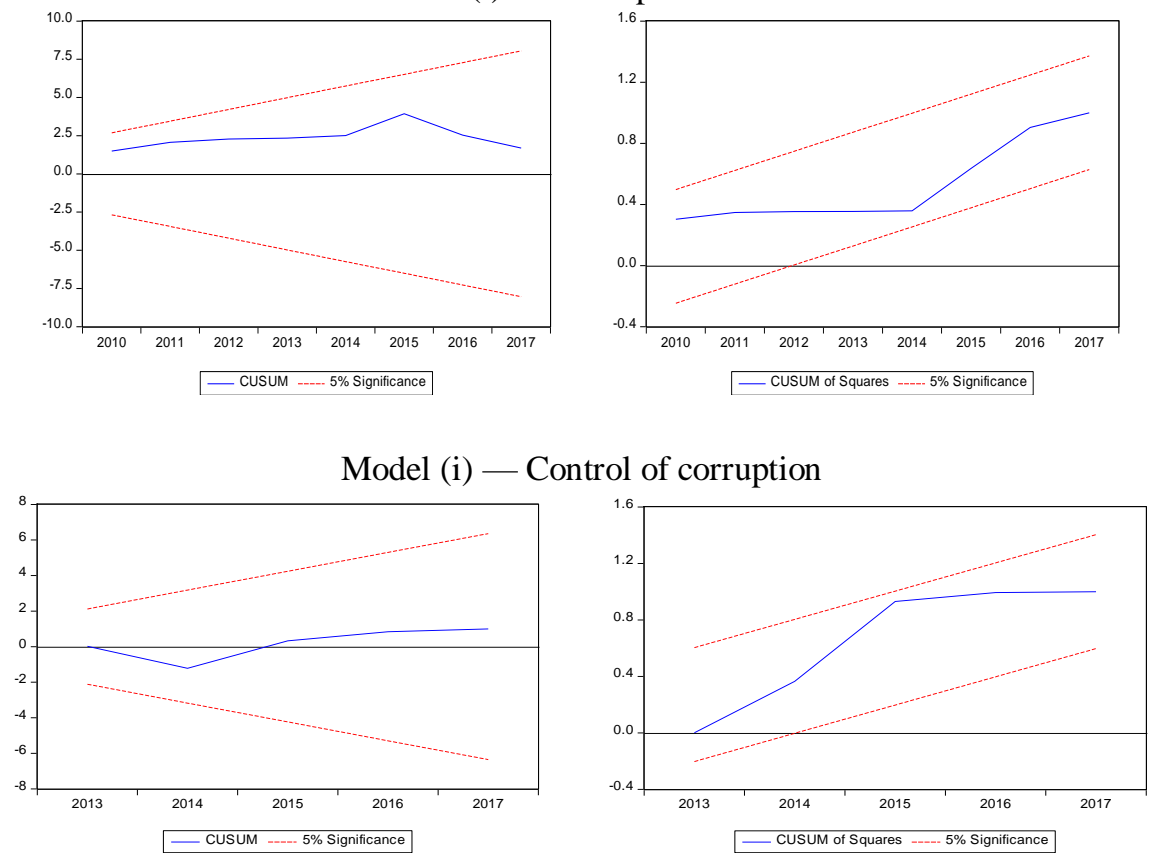

Figure 2: cusum (left) \& cusumsq (right) 
Table 5.Pairwise Granger Causality Test

\begin{tabular}{|c|c|c|c|c|c|}
\hline Model & Hull hypothesis & & & $\begin{array}{l}\text { F- } \\
\text { statistic }\end{array}$ & Prob. \\
\hline \multirow[t]{2}{*}{$\begin{array}{l}\text { Model } \\
\text { (i) }\end{array}$} & $\begin{array}{l}\text { CORRUPTION_INDEX does } \\
\text { LOGPUB }\end{array}$ & not Granger & Cause & 2.80 & $0.09^{x / x}$ \\
\hline & $\begin{array}{ll}\text { LOGPUB does } & \text { not } \\
\text { CORRUPTION_INDEX } & \end{array}$ & Granger & Cause & 3.01 & $0.07^{\text {柿 }}$ \\
\hline \multirow[t]{2}{*}{$\begin{array}{l}\text { Model } \\
\text { (ii) }\end{array}$} & $\begin{array}{l}\text { CONTROL_OF_CORRUPTION } \\
\text { Cause LOGPUB }\end{array}$ & does not & Granger & I.65 & 0.22 \\
\hline & $\begin{array}{l}\text { LOGPUB does not } \\
\text { CONTROL_OF_CORRUPTION }\end{array}$ & Granger & Cause & I. 57 & 0.23 \\
\hline
\end{tabular}

* indicates statistical significance at I0\%

In Table 5, the Granger causality results show that corruption index as the tendency to induce the rate of debt in the country, while the causality is also run in opposite direction. This implies that, in model (i), there is bi-directional causality between corruption index and public debt. However, both control of corruption and government debt do not Granger cause each other in model (ii). These findings depict little effectiveness on the part of corruption-based control mechanisms, including bureaucratic and fiscal adjustment mechanisms. One of the main factors that could be responsible for such ineffectiveness is that public policies' enforcement rate may be too low. Furthermore, the entrenchment of corruption in the public sector and social misalignment have led to a litany of compromising corrupt officials in the system, which undermine the application of governance principles and support for long-term strategic monitoring.

\section{Concluding Remarks}

It is increasingly recognized that good understanding on the corruption-related causes and remedies of the modern fiscal crisis would bolster informed decisions and key governance standards. Many of the governance weaknesses have been exacerbated by ingrained fiscal indiscipline and lack of effective bureaucratic provisions. These concerns necessitate ongoing research efforts aimed at galvanizing the best compilation of perspectives on the role of public institutions in debt accumulation process. Hence, this study examines the long run and short run effect of corruption on public debt in Nigeria over the period of 1996 to 2017 using ARDL bound test to cointegration analysis. While pairwise Granger causality test was applied to know the causal direction between corruption indicators (corruption index and control of corruption) public debt, other significant tests were also checked for.

New empirical evidence documented reveals that both corruption index and control of corruption have an insignificant adverse effect on public debt in the long run, but with a significant influence in the short run. Considering the long-term implication, the current anti-corruption efforts might not be well suited to the improvement of public debt management strategy or perhaps ineffective in enhancing strategic monitoring and sustainable fiscal standards. Thus, entrenched corruption in the public sector may widen the structural gaps. Nonetheless, it is emphasized that effective corruption control measures could mitigate spiralling incidence of government debt. More findings from the analysis indicate that there exists bi-directional causality between corruption index and public debt, whereas none is found between control of corruption and public debt. The study suggests that strong corruption-based control mechanisms are fundamentals to decreasing fiscal deficits and debt reduction. On the contrary, fiscal imprudence and the rising incidence of indebtedness could be worsened by large - scale government expenditures on unsustainable projects. Overall, a significant insight distills from the findings is that the goal of attaining global financial stability and fiscal sustainability through sound regulatory framework has embodied the provisions that enhance corruption-reducing measures and institutional standards to curb persistent debt accumulation.

\section{References}

Adewale, S. B. (20I I). The crowding-out effects of corruption in Nigeria: An empirical study. Journal of Business Management and Economics, 2(2): 059-068.

Arusha C., \& friedrich S. (2013). How Does Corruption Affect Public Debt? Working Paper No. I322 December 2013.

Arusha C., Ratbek D., \& Friedrich S. (2017). How Does Corruption Affect Public Debt? World Development, 90: II 5-I27.

Bailey, S.J. (2004). Structural Gaps in Public Finance: Strategic Public Finance. I79-I80.

Benfratello, L., Del Monte, A. \& Pennacchio, L. (2018). Corruption and public debt: a cross-country analysis. Applied Economics Letters, 25(5), 340-344, DOI: I0.I080/I350485I.2017.132I83I.

Buehn, A. \& Schneider, F. (2009). Shadow Economies and Corruption All Over the World: Revised Estimates for I20 Countries. Economics: The Open-Access, Open-Assessment E-Journal, I (2007-9): I-53 (Version 2). http://dx.doi.org/I0.5018/economics-ejournal.ja.2007-9.

Butler, A., Fauver, L. and Mortal, S. (2009). Corruption, Municipal Connections, and Municipal Finance. Review of Financial Studies, 22(7): 2873-2905. 
Cooraya, A., Dzhumashev, R. \& Schneider, F. (2017). How Does Corruption Affect Public Debt? An Empirical Analysis. World development, Vol 90: I I5-I27, https://doi.org/I0.I0I6/j.worlddev.20I6.08.020

Delavallade, C. (2006). Corruption and Distribution of Public Spending in Developing Countries. Journal of Economics and Finance, 30 (2): $222-39$.

Depken, C. A. \& LaFountain, C.L. (2006). Fiscal Consequences of Public Corruption: Empirical Evidence from State Bond Ratings, Public Choice, 126 (I-2): $75-85$.

Dzhumashev, R. (2014a). Corruption and growth: The role of governance, public spending, and economic development. Economic Modelling, 37, issue C, 202-2I5.

Dzhumashev, R., (20I4b). The two-way relationship between government spending and corruption and its effects on economic growth. Contemporary Economic Policy, 32, 403-4I9.

Engle, R.F. \& Granger, C.J. (I987). Cointegration and error-correction-representation, estimation and testing. Econometrica, 55, pp. 25I-278.

Friedman, E., Johnson, S. \& Kaufmann, D. \& Zoido-Lobaton, P., (2000). Dodging the grabbing hand: the determinants of unofficial activity in 69 countries. Joumal of Public Economics, Elsevier, 76(3): 459-493.

Grechyna, D. (2012). Public Corruption and Public Debt: Some Empirical Evidence. http://papers.ssm.com/s013/papers.cfm?abstract_id=2052974 [accessed November 20, 2016 ].

Gupta, S., De Mello, L. \& Sharan, R. (200I). Corruption and Military Spending, European. Journal of Political Economy. I7: $749-77$.

Hall, R.E. \& Charles I. Jones, C.I. (I999). Why Do Some Countries Produce So Much More Output per Worker than Others? Quarterly Journal of Economics, II4 (I): 83 - II6.

Haug, A. (2002). Temporal Aggregation and the Power of Cointegration Tests: A Monte Carlo Study. Oxford Bulletin of Economics and Statistics 64, 399-4I2.

Johansen, S. \& Juselius, K. (1990). Maximum likelihood estimation and inference on cointegration with application to the demand for money. Oxford Bulletin of Economics and Statistics, 52, pp. I69 - 210.

Johansen, S. (I99I). Estimation and hypothesis testing of co-integration vectors in Gaussian vector autoregressive models. Econometrica, 59, pp. I55I - I580.

Johnson, S. Kaufmann, D. and Shleifer, A. (1997). The Unofficial Economy in Transition. Brookings Papers on Economic Activity, 28 (2): I59-240.

Kaufmann, D. (2010). Can Corruption Adversely Affect Public Finances in Industrialized Countries? Brookings Institution, April I9. https://www. brookings.edu/opinions/can-corruption-adversely-affect-public-finances-inindustrializedcountries/ [accessed November 20, 2016].

Kaufmann, D., Kraay, A., \& Mastruzzi. M. (2010). The Worldwide Governance Indicators: Methodology and Analytical Issues. Available online: www.govindicators.org (accessed on I9 April 2016).

Kraay, A., Zoido-Lobaton, P. and Kaufmann, D. (1999). Governance Matters. Policy Research Working Paper no. 2196, World Bank. http://elibrary.worldbank. org/doi/book/I0.1596/I8I3-9450-2I96 [accessed November 20, 2016 ].

Kumar, M.S \& Woo, J. (2010). Public Debt and Growth. IMF Working Papers, No. I0/I74, International Monetary Fund.

Leadership Nigeria Newspaper (2018). Nigeria’s Rising Debt Profile.

Liu, C. (2017). Corruption and State and Local Government Debt Expansion. Public Administration Review, 77 (5): $681-690$.

Liu, C. and Mikesell, J.L. (20I4). The Impact of Public Officials' Corruption on the Size and Allocation of U.S. State Spending. Public Administration Review, 74 (3): 346 - 59.

Luigi, B., Alfredo, D. M. \& Luca, P. (2018). Corruption and public debt: a cross-country analysis. Applied Economics Letters, Taylor \& Francis Journals, 25(5): 340-344.

Mauro, P. (1995). Corruption and Growth, Quarterly Journal of Economics, IIO (3): 68 I - 7I2.

Mauro, P. (1998). Corruption and the Composition of Government Expenditure. Journal of Public Economics, 69 (2): 263 79.

Narayan, P. (2005): The Saving and Investment Nexus for China: Evidence from Co-integration Tests. Applied Economics, 37: I979-1990.

Njangang N. H. (2018). Impact of Corruption on Public Debt: Evidence from Sub-Saharan African Countries. American Journal of Economics, 8 (I): I4-17, doi: 10.5923/j.economics.20180801.03.

Obadan, M. (2002). Corruption, Public Investment and Growth in Nigeria: Some Stylist Facts. NESG Economic Indicators, $2(2)$.

Obialor, C.F. \& Ugochukwu, O.H. (2017). Corruption and Effective Public Service Performance in Nigeria. International Journal of Advanced Studies in Economics and Public Sector Management, 5 (3).

Ojukwu, C.C. \& Shopeju, J.O. (2010). Elite corruption and the culture of primitive accumulation in 2I ${ }^{\text {st }}$ Century Nigeria.

Osunyikanmi, P.O. (2007). Development Implication of Nigeria’s Economic Crisis. Journal of Development Perspective, 2(I): 34-59. 
Pani, M. (1996). Corruption and public debt: can a financial crisis result from dishonest political control? Giornale degli Economisti e Annali di Economia Nuova Serie, 55(I): I 17-I32, https://www.jstor.org/stable/23247932.

Pesaran, H. \& Shin, Y. (1997): An Autoregressive Distributed Lag Modeling Approach to Co-integration Analysis, Cambridge, England.

Pesaran, M. H., Shin, Y. \& Smith, R.J. (200I). Bounds testing approaches to the analysis of level relationships. Journal of Applied Econometrics, 16, 289-326.

Reinhart, C. M, Reinhart, V.R. \& Rogoff, K.S. (2012). Public debt overhangs: Advanced economy episodes since I800. Journal of Economic Perspectives, 26(3): 6986.

Rose-Ackerman, S. (1997). The Pursuit of Absolute Integrity: How Corruption Control Makes Government Ineffective. Journal of Policy Analysis and Management, I6 (4): 66I - 64.

Schneider, F., Buehn, A., \& Montenegro, C.E. (2010). Shadow economies all over the world: new estimates for I62 countries from 1999 to 2007 (English). Policy Research working paper; no. WPS 5356. Washington, DC: World Bank.

Shleifer, A. and Vishny, R. (1993). Corruption. Quarterly Joumal of Economics, I08 (3): 599 - 6 I7.

Smith, M.S. (1994): Second language learning: theoretical foundations. London: Longman. 235 pp

Tanzi, V. (1998). Corruption and the Budget: Problems and Solutions. In Economics of Corruption. Edited by Arvind K. Jain, II - 28. Norwell, MA: Kluwer Academic.

Tanzi, V. and Davoodi, H.R. (1997). Corruption, Public Investment, and Growth. Working Paper no. 97/I39, International Monetary Fund. https://www.imf.org/external/pubs/ft/wp/wp97139.pdf [accessed November 20, 2016].

Wei, Y. W. (200I). Negative Alchemy? Corruption, Composition of Capital Flows, and Currency Crises. NBER Working Paper No. 8187, DOI: I0.3386/w8187.

\section{Copyrights}

Copyright for this article is retained by the author(s), with first publication rights granted to the journal. This is an open-access article distributed under the terms and conditions of the Creative Commons Attribution license (http://creativecommons.org/licenses/by/4.0/). 